occurs during the acute urethritis stage of the disease, and the average time after the acute attack of gonorrhoea at which the iritis appeared worked out at 9 years in one series of 250 cases, and 14 years in another." The paragraphs on the examination of the material obtained by prostatic and vesicular massage and on the relation between so-called rheumatic iritis and the gonococcus had better be read in the original. One more quotation may be given, namely the opening sentence on the tests for tubercle. "The tests for tuberculosis of the eye are few, and of little real value as proof tests," and the final sentence on this subject (the last sentence also of the article), " The presence of a positive von Pirquet test does not mean that the eve condition is a tuberculous one."

ERnest Thomson.

\title{
CORRESPONDENCE
}

\section{BEDS OCCUPIED IN OPHTHALMIC AND GENERAL HOSPITALS}

To the Editor of The British Journal of Ophthalmology.

SIR,-In order to get a true perspective of the ophthalmic work done in Great Britain it is useful from time to time to look up some statistics about the leading eye hospitals in that excellent publication Burdett's " Hospitals and Charities."

Extracting a few figures dealing with the question of the size of the eye hospitals in the provinces and in London for the year 1929 , they are as follows :

\begin{tabular}{|c|c|c|c|c|}
\hline & $\begin{array}{l}\text { No. of } \\
\text { beds. }\end{array}$ & $\begin{array}{l}\text { Average No } \\
\text { of beds con- } \\
\text { stantly full. }\end{array}$ & $\begin{array}{c}\text { No. of } \\
\text { in-patients. }\end{array}$ & $\begin{array}{c}\text { No. of } \\
\text { out-patients. }\end{array}$ \\
\hline $\begin{array}{llll}\text { Moorfields } \quad \ldots & \ldots & \ldots\end{array}$ & $\begin{array}{l}138 \text { (only } 120 \\
\text { occupied) }\end{array}$ & 113 & 2,581 & 45,116 \\
\hline $\begin{array}{l}\text { Royal Westminster } \\
\text { Ophthalmic Hospital } \\
\text { Central London Ophthalmic } \\
\text { Hospital }\end{array}$ & $\begin{array}{l}86 \\
40\end{array}$ & - & - & $\begin{array}{c}- \\
14,473\end{array}$ \\
\hline Royal Eye Hospital ... $\quad \ldots$ & 46 & 33 & 666 & 22,803 \\
\hline Western Ophthalmic Hospital & 36 & - & 一 & - \\
\hline $\begin{array}{l}\text { Manchester Royal Eye } \\
\text { Hospital }\end{array}$ & 148 & 119 & 2,536 & 32,809 \\
\hline Birming ham Eye Hospital ... & 115 & 73 & 1,871 & 43,648 \\
\hline Glasgow Eye Infirmary & 110 & 92 & 1,901 & 32,053 \\
\hline
\end{tabular}


This table brings out very clearly the large size of the provincial ophthalmic hospitals. Somewhat to one's surprise it shows that the Manchester Royal Eye Hospital is the largest eye hospital in Great Britain and possibly in the world.

Someone might object to this statement and say that with eye hospitals the number of new out-patients seen during the course of the year is a better criterion of efficiency than the number of beds available for in-patients.

Hospitals, however, have always been measured by their bed strength and not by the number of patients seen.

I have omitted the figures of my own hospital the Royal Westminster Ophthalmic Hospital and also those of the Western Ophthalmic Hospital as both of these institutions have been in the throes of rebuilding and have not been fully open the whole period, consequently their figures are not normal.

The table brings out the fine average of beds kept constantly full enjoyed by Moorfields.

It also shows the more generous in-patient treatment as compared to the number of out-patients which is enjoyed by the Manchester citizen.

Yours faithfully,

LoNDON,

Adrian Caddy.

March, 1930.

\section{"LEAH, TENDER OR SORE-EYED"}

To the Editor of The British Journal of Ophthalmology.

SIR,- The subject of Leah's eyes referred to in a note in the journal for April (p. 190) is one that presents considerable difficulty to Bible scholars. In the original Hebrew Leah's eyes are described as being $ת i \supseteq\urcorner$ and this adjective has had a wide variety of interpretations, as can be seen from the different meaning attached to it in the standard translations.

The reading of tender-eyed in the authorised version is supported by the French version in the Hexaglot Bible: "Mais Léa avait les yeux tendres, et Rachel était de belle taille et belle à voir." The authorised German version, on the other hand, agrees with the Septuagint in regarding Leah as weak-sighted. "Aber Lea hatte ein blödes Gesicht, Rachel war hübsch und schön." The septua-

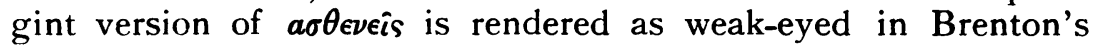
translation: "And the eyes of Leah were weak. But Rachel was beautiful and exceedingly fair in countenance," but it must be 